\title{
Comparison of Hardness and Surface Roughness of Two Denture bases Polymerized by Different Methods
}

\author{
Farideh Bahrani, Anahita Safari, Mahroo Vojdani, Ghasem Karampoor
}

\begin{abstract}
Purpose: The aim of this study was to evaluate mechanical property hardness and surface roughness $(\mathrm{Ra})$ of different polymerization acrylic resins used for denture bases.
\end{abstract}

Materials and methods: A total of 30 specimens were prepared and divided in two groups. A total of 15 samples were processed by the compression molding technique using Meliodent (heatcured). Another 15 samples were processed with cold-cured resin FuturaGen via the injection molding technique.

Hardness testing was conducted using a Vickers hardness tester. The Ra test was performed by a profilometer. Data were analyzed using the independent sample t-test and differences were statistically significant at the 0.05 level.

Results: The Vickers hardness numbers (VHN) were $20.8 \pm$ 2.39 for Meliodent and $21.18 \pm 1.42$ for FuturaGen, which was not significantly different $(p>0.05)$. The Ra of Meliodent was $0.92 \pm 0.23 \mu \mathrm{m}$ and for FuturaGen it was $0.84 \pm 0.37 \mu \mathrm{m}$. There were no significant changes in roughness.

Conclusion: The hardness and Ra of Meliodent and FuturaGen were not significantly different. Therefore, we recommend the use of FuturaGen for manufacturing denture base materials.

Keywords: Acrylic resin, Surface roughness, Hardness value.

How to cite this article: Bahrani F, Safari A, Vojdani M, Karampoor G. Comparison of Hardness and Surface Roughness of Two Denture bases Polymerized by Different Methods. World J Dent 2012;3(2):171-175.

Source of support: Nil

Conflict of interest: None declared

\section{INTRODUCTION}

One of the most widely used materials in prosthetic dentistry is polymethyl methacrylate, a material which has been used for denture base manufacturing since 1937..$^{1,2}$

Heat-cured polymethyl methacrylate (PMMA) resin has been widely used as a denture base material because of its excellent esthetics, low water sorption and solubility, relative lack of toxicity, reparability and simple processing technique. One of the conventional methods for curing resin is the compression molding technique. ${ }^{3-5}$ This method is advantageous due to ease of processing, its familiarity for dentists and technicians, and the lack of a need for any sophisticated or expensive equipment. Disadvantages of this technique may give rise to dimensional changes and inaccuracies in the fit of the denture base. Therefore the popularity and relative simplicity of the compression molding technique are usually over shadowed by the highprocessing stresses induced in the resin during polymerization. ${ }^{6-8}$

Another type of resin is the chemically activated or autopolymerizing resin. Chemically activated resins are much less frequently used for denture base fabrication than heat-activated resins. In comparison with heat-activated resins, chemically activated resins have a higher residual monomer content of 3 to $5 \%$. Polymerization in these acrylic resins is not as complete as heat-activated resins, resulting in inferior mechanical properties and dramatically compromising denture base biocompatibility. The materials exhibit higher solubility and inferior color stability due to oxidation of the amine accelerator. ${ }^{9,10}$ Creep rates are usually high, particularly under increased stresses. Chemically activated resins, most often when compression molded, display less shrinkage on polymerization than their heatactivated counterparts, which leads to greater dimensional accuracy. This could be attributed to a reduction in residual stresses that have been induced during the processing cycle. $^{11,12}$

Development of alternative materials, such as FuturaGen, a cold-cure PMMA, is a breakthrough in denture base materials. The advantages of FuturaGen are: Less shrinkage, less processing time, ease of polishing, extremely smooth glass surface, outstanding denture adhesion characteristics, and significant plaque reduction due to its homogeneously smooth surface. ${ }^{13,14}$ The manufacturer has improved the quality of this material due to modification and binding ability which has resulted in color stability. According to the manufacturer, the lack of a monomer results in higher strength when compared to heat-cured resin.

The injection molding technique is used for curing FuturaGen, which is similar to other injection methods. This technique when compared with the compression molding technique has a reduced processing time, lower cost, lower skin sensitivity to the evaporated monomer, and availability of the resin reservoir to compensate for acrylic resin shrinkage. ${ }^{15,16}$

The type of processing could affect resin mechanical properties, such as surface roughness and hardness. Surface roughness of the denture base material is important, as it affects the oral health of the tissue in direct contact with the denture. Most microorganisms present intraorally, 
particularly those responsible for caries, periodontal disease, and denture stomatitis, can only survive in the mouth, if they adhere to a non-shedding oral surface and begin to form colonies. ${ }^{17}$ The surface properties of any denture base material are of particular concern as studies of these materials have shown a direct link between surface roughness, the accumulation of plaque and adherence of Candida albicans. ${ }^{18,19}$ The increased presence of Candida species is reported in denture-related stomatitis.

A clinically acceptable threshold level of surface roughness ( $\mathrm{Ra}$ ) of $0.2 \mu \mathrm{m}$ where no further reduction in plaque accumulation is expected in prosthetic and dental restorative materials have been discussed in the literature. ${ }^{20-23}$ Hardness is defined as the resistance of a material to permanent surface indentation or penetration. Hardness provides a possible indication of the abrasiveness of the denture material. The surface properties of acrylic resin can be affected by hardness, which is characteristic of the ease of finishing the material as it is resistant to in-service scratching during cleansing. ${ }^{24,25}$ There are many studies about the Ra and hardness of different heat and cold-cured denture base materials with different processing methods. However, there is no published article that analyzes the mechanical properties of FuturaGen, as a representative of the cold-cured denture base. Therefore, this study aims to compare the Ra and hardness of two types of denture base materials (Meliodent and FuturaGen) utilizing different processing methods.

\section{MATERIALS AND METHODS}

In this study, we chose Meliodent, the conventionally heat cured denture base material and FuturaGen, the self-cure acrylic resin. Names of the resins, manufacturers, compositions, lot numbers and polymerization conditions are presented in Table 1.

Test specimens were produced in molds prepared by insertion of stainless steel dies into silicon rubber of dimensions $12 \times 12 \times 3 \pm 0.2 \mathrm{~mm}$ (Zetalabor, Zermack, Rovigo, Italy), which were further supported by dental stone within the flask. Specimen preparation was carefully standardized.

The compression molding technique was used to process 15 samples of Meliodent according to the manufacturer's instructions, at a ratio of 2.2 (powder) to $1 \mathrm{ml}$ (liquid). Meliodent was heat polymerized in a thermostatically controlled water bath at $73 \pm 1^{\circ} \mathrm{C}$ for 90 minutes. After samples were allowed to cool, the excess and flashes were trimmed. Specimens were manually wet polished using a circular motion with sequences of 600, 800, 1000 and 1200 grit silicon carbide paper. All specimens were washed in an ultrasonic bath between each grade of grit paper.

Another 15 specimens were processed with the coldcure resin, FuturaGen. This resin was processed by the injection molding technique with the use of a unipress machine (Schutz Dental GmbH, Germany). The powder/ liquid ratio of this resin mixture was 14:6. The mixture was injected according to the manufacturer's instructions, after which any flash and excess were removed by polishing using progressively finer grit grades (600-1200) of silicon carbide paper with the intent to obtain a smooth, flat surface. Specimens were cleaned in distilled water for 2 minutes in an ultrasonic bath.

Ra of the acrylic specimens was measured by a profilometer (Surfcorder SE 1700, Kosaka, Japan) that had a $0.01 \mu \mathrm{m}$ resolution calibrated to a specimen length of $0.8 \mathrm{~mm}, 2.4 \mathrm{~mm}$ percussion of measure and $0.5 \mathrm{~mm} / \mathrm{sec}$. Three readings were obtained for each specimen and a mean value was calculated.

To determine Vickers values, specimens were measured by applying a load of $30 \mathrm{~g}$ for $30 \mathrm{~s}$ using a digital hardness tester (Otto Wolpert, Werke GmbH, Ludwigshafen, Germany). Each specimen was subjected to three indentations (one on the center, two on the border) and the average value was calculated for each group.

We compared both hardness and roughness between Meliodent and FuturaGen. Descriptive statistics was carried out for each test. Data were analyzed with the independent

\begin{tabular}{|c|c|c|c|c|c|c|}
\hline $\begin{array}{l}\text { Name of } \\
\text { resin }\end{array}$ & $\begin{array}{l}\text { Type of } \\
\text { polymerization }\end{array}$ & Powder & Liquid & $\begin{array}{l}\text { Mode of } \\
\text { preparation }\end{array}$ & Manufacturer & Lot no. \\
\hline Meliodent (M) & Heat-cured & $\begin{array}{l}\text { Polymethyl- } \\
\text { methacrylate } \\
\text { (MMA) }\end{array}$ & $\begin{array}{l}\text { Methyl- } \\
\text { methacrylate } \\
\text { (MMA) }\end{array}$ & $\begin{array}{l}73^{\circ} \mathrm{C} \text { for } \\
90 \text { mins } \\
100^{\circ} \mathrm{C} \text { for } \\
30 \text { mins }\end{array}$ & $\begin{array}{l}\text { Heraeus Kulzer, } \\
\text { Berkshire, } \\
\text { Germany }\end{array}$ & $\begin{array}{l}\text { Powder: A1397B } \\
\text { Liquid: } 012155\end{array}$ \\
\hline FuturaGen (F) & Cold-cured & $\begin{array}{l}\text { Polymethyl- } \\
\text { methacrylate, } \\
\text { barbituric } \\
\text { acid, titanium oxide, } \\
\text { feric oxide }\end{array}$ & $\begin{array}{l}\text { Polymethyl- } \\
\text { methacrylate, } \\
\text { Cu+, Bis-MA }\end{array}$ & $\begin{array}{l}\text { In room } \\
\text { temperature } \\
\text { for } 20-30 \text { mins }\end{array}$ & $\begin{array}{l}\text { Schütz Dental, } \\
\text { GmbH, Rosbach, } \\
\text { Germany }\end{array}$ & Powder: 0406021 \\
\hline
\end{tabular}


sample t-test. Differences were significant at the $\mathrm{p}<0.05$ level.

\section{RESULTS}

The mean, standard deviation, as well as minimum and maximum values for Vickers hardness number (VHN) and Ra values are presented in Tables 2 and 3. The Ra mean and SD for Meliodent was $0.92 \pm 0.23 \mu \mathrm{m}$, whereas for FuturaGen it was $0.84 \pm 0.37 \mu \mathrm{m}$.

There was no statistically significant difference observed between surface roughness of Meliodent and FuturaGen $(\mathrm{p}=0.7)$. The mean and SD VHN for Meliodent was $20.8 \pm$ 2.39 , whereas it was $21.18 \pm 1.42$ for FuturaGen, which was not significantly different $(p=0.6)$.

\section{DISCUSSION}

The objective of this study to compare Ra and hardness between two types of denture base acrylic resins (Meliodent and FuturaGen) using two different processing methods. Based on the results of this study, the conventional heatpolymerized acrylic resin (Meliodent) had lower microhardness values when compared with FuturaGen, the injection molded autopolymerized acrylic resin. However, there was no significant difference observed between specimens with different polymerizations $(p>0.05)$.

FuturaGen specimens produced a rougher surface than Meliodent, however this was also not significantly different $(\mathrm{p}>0.05)$.

Acrylic reins contain a group of characteristics that make them acceptable and advantageous for prostheses manufacturing, such as biocompatibility, the possibility of being relined, low specific weight, insolubility, cost and less complex manufacturing. Nevertheless, these materials also have some less desirable properties, such as the presence of microporosities, low resistance to fracture, and susceptibility to abrasion. Advantages of conventional heatactivated PMMA with a compression-molded technique are its good biocompatibility, color stability, insolubility in oral fluids, ability to chemically bond to resin teeth, acceptable dimensional stability, ease of repair and fabrication and cost effectiveness. Disadvantages include its low thermal conductivity, low impact and flexural strengths, short fatigue life and low abrasional resistance. The advantages of chemically activated PMMA are its dimensional accuracy, ease to deflask, and processing is less time-consuming. Disadvantages of cold-cured processing are its high residual monomer content, high creep rates, reduced stiffness, lower fatigue strength, color instability, high solubility and tooth bond failures in pour resins.

The development of alternative materials, such as FuturaGen, as a cold-cure PMMA, is considered a breakthrough in denture base materials. According to the manufacturer, because of the change in initiator system and the replacement of changed copper and barbituric acid ions, instead of a tertiary amine in FuturaGen, the amount of residual monomer in this resin is similar to heat-cured resin. Therefore, the physical properties of FuturaGen have improved. Assuming that hardness and Ra properties are indicative of the ease with which the material is scratched or abraded, thus dental prostheses made of acrylic resins with low surface hardness and Ra will probably be damaged by mechanical brushing, thus compromising their Ra and favoring plaque retention and pigmentation. Hardness evaluation has been frequently used to predict denture base materials.

Farnia et al have tested five types of acrylic resins: One type of microwave polymerized, one autopolymerized, and three conventional heat-polymerized. Their specimens were submitted to Vicker hardness testing with a $25 \mathrm{~g}$ load for $30 \mathrm{~s}$. Their investigation showed that conventional heat polymerized (ViPi cril) had a higher hardness value (17.73 \pm 2.3) compared to the others. ${ }^{26}$

Based on the results of our study, the conventional heat polymerized acyclic resin (Meliodent) presented with a microhardness value of $20.83 \pm 2.39$ and the

Table 2: Mean roughness value ( $\mathrm{Ra}, \mu \mathrm{m})$, standard deviation $( \pm)$, minimum and maximum value of Meliodent and FuturaGen

\begin{tabular}{llllll}
\hline Resin & Mean & Max & Min & $S D$ & $p=0.7$ \\
\hline Meliodent & 0.92 & 2.5 & 0.17 & 0.23 & - \\
FuturaGen & 0.84 & 1.5 & 0.23 & 0.37 & - \\
\hline
\end{tabular}

Table 3: Mean hardness value (VHN) standard deviation ( \pm ), minimum and maximum value of Meliodent and FuturaGen

\begin{tabular}{llllll}
\hline Resin & Mean & Max & Min & SD & $p=0.6$ \\
\hline Meliodent & 20.8 & 26.43 & 18.3 & 2.39 & - \\
FuturaGen & 21.18 & 25.73 & 17.8 & 1.42 & - \\
\hline
\end{tabular}


injection-molding autopolymerization resin (FuturaGen) had a $21.18 \pm 1.42$ microhardness value. Therefore, FuturaGen had a hardness value similar to Meliodent, the conventional heat polymerized resin. This possibly occurred because of a reduction in the residual monomer content of FuturaGen.

Ali et al evaluated three types of acrylic resin, Meliodent (heat-cured), Probase (auto-cured), and Eclips (light- and heat-cured). The hardness values were $17 \pm 0.4$ for Meliodent, $16 \pm 0.4$ for Probase and $19.4 \pm 0.7$ for Eclips. ${ }^{27}$ A comparison among the three polymers showed a significant difference in surface hardness $(p>0.05)$. The surface hardness of light- and heat-cured (Eclips) was significantly higher than those obtained for heat-cured (Meliodent) and auto-cured (Probase) denture base systems. In our study, the hardness values observed for FuturaGen and Meliodent agreed with those reported for polymethylmethacrylate denture teeth (17.0) and heat polymerization denture base resins (18.6), which were similar to results obtained by Budai et al. ${ }^{28}$ In the current study, the hardness of FuturaGen was 21.18, while for Meliodent it was 20.8 which was not statistically significant.

The autopolymerizing acrylic resins tend to have a rougher surface than other acrylic resins. One possible explanation could be that the autopolymerizing acrylic resin polymer may have a larger acrylic resin precursor than the others. Our study has shown no significant difference between hardness and Ra of Meliodent and FuturaGen. This result may be due to the improved physical properties of FuturaGen which has been reported as a perfect autopolymer without any complications.

Berger et al have selected four types of acrylic resins: Autopolymerized, heat processed, injection molded and microwaveable. They reported a significant difference in Ra between the types of acrylic resins. ${ }^{29}$ The heat-processed acrylic resin used benzoyl peroxide and di-isobutylazonitrile as initiators whereas the auto polymerizing acrylic resin used benzoyl peroxide and free radicals as initiators. Perhaps the initiator in each acrylic resin system played a role in differences found in $\mathrm{Ra}$.

The mean Ra value of all materials were lower than those reported by Zissis et al whose mean values ranged from 0.7 to $4.4 \mu \mathrm{m}$. However, the results of our study revealed mean $\mathrm{Ra}$ values of $0.84 \mu \mathrm{m}$ for FuturaGen and $0.92 \mu \mathrm{m}$ for Meliodent, which agreed with the results by Zissis et al. ${ }^{30}$ Results of this study showed mean $\mathrm{Ra}$ values near the threshold $\mathrm{Ra}(0.2 \mu \mathrm{m})$ for bacterial retention, below which no further reduction in bacterial accumulation would be expected.
The present study showed that although the Ra of FuturaGen was greater $(0.84 \mu \mathrm{m})$ than Meliodent $(0.42 \mu \mathrm{m})$, it was not statistically significant.

Because of these results, it could be suggested that FuturaGen can be used instead of Meliodent when necessary as denture base materials. Some advantages of FuturaGen are less shrinkage, less processing time, easy and quick to polish, extremely smooth surface, outstanding denture adhesion characteristics, and significant plaque reduction due to a homogeneously smooth surface.

In the present study, no statistical differences in roughness and hardness of Meliodent and FuturaGen were observed. A small, but not statistically significant increase, in hardness and Ra of FuturaGen was detected.

Future clinical studies may be necessary to confirm the long-term behavior of Ra and hardness of these materials. Additionally, the other physical properties should be investigated.

\section{ACKNOWLEDGMENT}

The authors wish to express their appreciation to the Research Council of the College of Dentistry, Shiraz University of Medical Sciences for their support in the clinical part of this study.

\section{REFERENCES}

1. Kuhar M, Funduk N. Effects of polishing techniques on the surface roughness of acrylic denture base resins. J Prosthet Dent 2005 Jan;93(1):76-85.

2. Meșe A. Effect of denture cleansers on the hardness of heat- or auto-cured acrylic- or silicone-based soft denture liners. Am J Dent 2007 Dec;20(6):411-15.

3. Oliveira LV, Mesquita MF, Henriques GE, Consani RL, Fragoso WS. Effect of polishing technique and brushing on surface roughness of acrylic resins. J Prosthodont 2008 June;17(4): 308-11.

4. Braun KO, Mello JA, Rached RN, Del Bel Cury AA. Surface texture and some properties of acrylic resins submitted to chemical polishing. J Oral Rehabil 2003 Jan;30(1):91-98.

5. Rahal JS, Mesquita MF, Henriques GE, Nóbilo MA. Surface roughness of acrylic resins submitted to mechanical and chemical polishing. J Oral Rehabil 2004 Nov;31(11):1075-79.

6. Lee SY, Lai YL, Hsu TS. Influence of polymerization conditions on monomer elution and microhardness of autopolymerized polymethyl methacrylate resin. Eur J Oral Sci 2002 Apr; 110(2):179-83.

7. Monsenego P. Presence of microorganisms on the fitting denture complete surface: Study 'in vivo'. J Oral Rehabil 2000 Aug; 27(8):708-13.

8. Azevedo A, Machado AL, Vergani CE, Giampaolo ET, Pavarina AC, Magnani R. Effect of disinfectants on the hardness and roughness of reline acrylic resins. J Prosthodont 2006 Jul-Aug;15(4):235-42.

9. Memon MS, Yunus N, Razak AA. Some mechanical properties of a highly cross-linked, microwave-polymerized, injectionmolded denture base polymer. Int J Prosthodont 2001 May-Jun;14(3):214-18. 
10. Salim S, Sadamori S, Hamada T. The dimensional accuracy of rectangular acrylic resin specimens cured by three denture base processing methods. J Prosthet Dent 1992;67:879-81.

11. Hugget R, Zissis A, Harrison A, Dennis A. Dimensional accuracy and stability of acrylic resin denture bases. J Prosthet Dent 1992;68:634-40.

12. Nogueria SS, Ogle RE, Davis EL. Comparison of accuracy between compression and injection molded complete dentures. J Prosthet Dent 1999;82:291-300.

13. Garfunkel E. Evaluation of dimensional changes in complete dentures processed by injection pressing packs and pressure technique. J Prosthet Dent 1983;50:757-61.

14. Takahiro O, Seiichi K, Takashi N. Dimensional accuracy of acrylic resin maxillary denture base polymerized by a new injection pressing method. J Dent Mater 2004;23:348-52.

15. Drees S. Polymers used in dental prostheses. (Cited 2008 Mar); Available from: http:// www.Schuetz dental. De/FG- Material Safety - Data- Sheet. 333.0. Html.

16. Powers JM, Sakaguchi RL. Craig's restorative dental materials (12th ed). Philadelphia: Mosby Elsevier 2006;513-43.

17. Morgan TD, Wilson M. The effects of surface roughness and type of denture acrylic on biofilm formation by Streptococcus oralis in a constant depth film fermentor. J Appl Microbiol $2001 \mathrm{Jul} ; 91(1): 47-53$.

18. Radford DR, Watson TF, Walter JD, Challacombe SJ. The effects of surface machining on heat cured acrylic resin and two soft denture base materials: A scanning electron microscope and confocal microscope evaluation. J Prosthet Dent 1997 Aug;78(2):200-08.

19. Radford DR, Challacombe SJ, Walter JD. Denture plaque and adherence of Candida albicans to denture-base materials in vivo and in vitro. Crit Rev Oral Biol Med 1999;10(1):99-116.

20. Yamauchi M, Yamamoto K, Wakabayashi M, Kawano J. In vitro adherence of microorganisms to denture base resin with different surface texture. Dent Mater J 1990 June;9(1):19-24.

21. Bollen CM, Lambrechts P, Quirynen M. Comparison of surface roughness of oral hard materials to the threshold surface roughness for bacterial plaque retention: A review of the literature. Dent Mater 1997 July;13(4):258-69.

22. Harrison Z, Johnson A, Douglas CW. An in vitro study into the effect of a limited range of denture cleaners on surface roughness and removal of Candida albicans from conventional heat-cured acrylic resin denture base material. J Oral Rehabil 2004 May;31(5):460-67.

23. Hermann C, Mesquita MF, Consani RL, Henriques GE. The effect of aging by thermal cycling and mechanical brushing on resilient denture liner hardness and roughness. J Prosthodont 2008 June;17(4):318-22.

24. Pinto Lde R, Acosta EJ, Távora FF, da Silva PM, Porto VC. Effect of repeated cycles of chemical disinfection on the roughness and hardness of hard reline acrylic resins. Gerodontology 2010 June;27(2):147-53.

25. Pavarina AC, Vergani CE, Machado AL, Giampaolo ET, Teraoka MT. The effect of disinfectant solutions on the hardness of acrylic resin denture teeth. J Oral Rehabil 2003 Jul;30(7): 749-52.

26. Farina AP, Cecchin D, Soares RG, Botelho AL, Takahashi JM, Mazzetto MO, Mesquita MF. Evaluation of Vickers hardness of different types of acrylic denture base resins with and without glass fibre reinforcement. Gerodontology 2010 Nov 11. doi: 10.1111/j.1741-2358.2010.00435.x.

27. Ali IL, Yunus N, Abu-Hassan MI. Hardness, flexural strength, and flexural modulus comparisons of three differently cured denture base systems. J Prosthodont 2008 Oct;17(7):545-49.

28. Buudai S, Ohtani T, Maeda Y, Ishii K, Nokubi T. Hardness of denture reline materials polymerized with different techniques. J Osaka Univ Dent Sch 1995 Dec;35:39-44.

29. Berger JC, Driscoll CF, Romberg E, Luo Q, Thompson G. Surface roughness of denture base acrylic resins after processing and after polishing. J Prosthodont 2006 May-Jun;15(3):180-86.

30. Zissis AJ, Polyzois GL, Yannikakis SA, Harrison A. Roughness of denture materials: A comparative study. Int J Prosthodont 2000 Mar-Apr;13(2):136-40.

\section{ABOUT THE AUTHORS}

\section{Farideh Bahrani}

DMD, Instructor, Department of Prosthodontics, School of Dentistry Shiraz University of Medical Sciences, Shiraz, Iran

\section{Anahita Safari (Corresponding Author)}

DMD-MSC, Assistant Professor, Department of Prosthodontics, School of Dentistry, Shiraz University of Medical Sciences, Shiraz, Iran Phone and Fax: 0098-711-628-9918, e-mail: safari.anahita@yahoo.com

\section{Mahroo Vojdani}

DMD-MSC, Associate Professor, Center of Biomaterial Research School of Dentistry, Shiraz University of Medical Sciences, Shiraz Iran

\section{Ghasem Karampoor}

DMD, Department of Prosthodontics, Faculty of Dentistry, Fars Iran 
